\title{
EFFECT OF SCALE, PROPORTION, AND WALKABILITY TO VISUAL TROTOAR QUALITY UNDER THE TERAS CIHAMPELAS
}

\author{
${ }^{1}$ Arvin Tekadtuera. ${ }^{2}$ Anindhita N. Sunartio, S.T., M.T. \\ ${ }^{1}$ Student in the Bachelor's (S-1) Study Program in Architecture \\ at Parahyangan Catholic University \\ ${ }^{2}$ Senior lecturer in the Bachelor's (S-1) Study Program in Architecture \\ at Parahyangan Catholic University
}

\begin{abstract}
The introduction the new infrastructures in the city of Bandung is being executed in order to tackle various urban problems, such as the lack of pedestrian-friendly spacse and the lack of public spaces throughout the city. In 2017, the Local Government of Bandung opened Teras Cihampelas, which is a skywalk-type of infrastructure that was built above Cihampelas Street in order to relocate the street vendors that had been occupying the pedestrianway in Jalan Cihampelas and to become a new public space. The new structure, in fact, affects the scale and proportion of the spaces between buildings along the road and reconfigurated the visual qualities of the existing street. Therefore, the visual experiences in the pedestrianway throughout Cihampelas Street had also affected by the changes of those factors.

The method used in this research is a qualitative triangulation method which can be done by mapping the typology of the space between buildings based on the existing buildings' intensity for further analysis which consist of scale and proportion analysis, and walkability analysis that was based on visual evaluation. The analysis of each typology will then be mapped and merged in each pedestrianways to provide the visual experiences of the pedestrian in Cihampelas Street.

The visual quality in Cihampelas Street appears to slightly exceed the minimum comfortability standard but still far from the maximum comfort for a pedestrianway. This problem appears because there are lacks of legibility and imageability that the pedestrian can grasp in most parts of the pedestrianway. But aside from those factors, other factors like transparency, complexity, and coherence in Cihampelas Street are highly achieved so that the pedestrianway can still be comfortably walkable by the pedestrian. $s$
\end{abstract}

Key Words: scale, proportion, visual quality, walkabillity, visual experience, pedestrian, qualitative triangulation method, Cihampelas Street

\section{PENGARUH SKALA, PROPORSI, DAN WALKABILITY TERHADAP KUALITAS VISUAL TROTOAR DI BAWAH TERAS CIHAMPELAS}

\author{
${ }^{1}$ Arvin Tekadtuera. ${ }^{2}$ Anindhita N. Sunartio, S.T., M.T. \\ ${ }^{1}$ Mahasiswa S1 Program Studi Arsitektur Universitas Katolik Parahyangan \\ 2 Dosen Pembimbing S1 Program Studi Arsitektur Universitas Katolik Parahyangan
}

\begin{abstract}
Abstrak- Penambahan infrastruktur baru di ruang kota Bandung dilaksanakan untuk mengatasi berbagai masalah terutama yang berhubungan dengan masalah kurangnya ruang jalan untuk pejalan kaki maupun fasilitas ruang publik. Pada tahun 2017, Pemerintah Kota Bandung meresmikan Teras Cihampelas yang merupakan infrastruktur jenis skywalk yang dibangun diatas Jalan Cihampelas untuk merelokasi PKL yang sebelumnya tersebar di area trotoar jalan dan menambah ruang publik. Namun, penambahan ini menyebabkan berubahnya skala dan proporsi ruang antar bangunan di sepanjang jalan dan juga menciptakan kualitas visual pejalan kaki yang berbeda. Oleh karena itu, pengalaman visual pada area trotoar yang dinikmati pejalan kaki dinilai berubah sehubungan dengan berubahnya faktor-faktor yang lain tersebut.

Metode yang digunakan pada penelitian ini adalah metode triangulasi kualitatif dengan melakukan pemetaan tipologi ruang antar bangunan berdasarkan intensitas bangunan yang ada, lalu dikaji tiap tipologinya dengan
\end{abstract}

\footnotetext{
${ }^{1}$ Corresponding Author: arvintekadtuera@gmail.com
} 
kajian skala dan proporsi, serta dengan kualitas pejalan kaki yang ditinjau dari segi visual. Analisis dari tiap tipologi tersebut kemudian dipetakan dan disatukan kedalam setiap ruas trotoar untuk mendapatkan pengalaman visual pejalan kaki di Jalan Cihampelas.

Kualitas visual pada Jalan Cihampelas memenuhi minimal standar kriteria kenyamanan yang ada tetapi masih jauh dari kenyamanan maksimal. Hal ini disebabkan oleh kurangnya legibility dan imageability pada sebagian besar trotoar yang dianalisis. Akan tetapi, faktor-faktor seperti transparansi, kompleksitas, dan koherensi pada Jalan Cihampelas dinilai sangat memenuhi sehingga membantu meningkatkan kualitas visual di Jalan tersebut.

Kata Kunci: skala, proporsi, kualitas visual, walkability, trotoar, pejalan kaki, metode triangulasi kualitatif, Jalan Cihampelas

\section{PENDAHULUAN}

Kota Bandung merupakan salah satu kota di Indonesia yang mempunyai pertumbuhan urban yang dinamis. Pertumbuhan ini selalu diiringi oleh transformasi, baik secara fisik spasial maupun tatanan kota, dan menyebabkan dampak tertentu terhadap kualitas ruang dan sosial masyarakat di sekitarnya. Secara fisik spasial, transformasi wajah kota Bandung yang dapat jelas terlihat adalah adanya pengembangan infrastruktur yang mengintervensi wajah kota tersebut dengan memasukkan fungsi baru tanpa menghilangkan fungsi yang sudah ada. Selain menghadirkan fungsi dan ruang yang baru, beberapa infrastruktur yang dirancang di kota Bandung tidak lepas dari pencanangan pemerintah terhadap solusi inovatif dalam mewujudkan Bandung Kota Kreatif yang menargetkan perkembangan sebuah area yang dianggap potensial untuk masyarakatnya tetapi mempunyai masalah tertentu. Contoh dari infrastruktur yang mengintervensi sebuah kawasan ini antara lain adalah Teras Cihampelas (Cihampelas Skywalk) yang berdiri sepanjang $450 \mathrm{~m}$ diatas Jalan Cihampelas.

Jalan Cihampelas dikenal sebagai jalan yang mempunyai pejalan kaki yang aktif, dipadukan dengan banyaknya area komersil dan pedagang kaki lima disepanjang pinggiran jalan. Akan tetapi, derasnya lalu lintas kendaraan pada area tersebut membuat kenyamanan aspek-aspek tersebut berkurang. Perancangan Teras Cihampelas ini merupakan sebuah inovasi di Indonesia dalam mengembangkan ruang untuk pejalan kaki diatas lalu lintas yang padat tersebut, serta memberikan relokasi tempat untuk para pedagang kaki lima yang berada di pinggiran jalan sehingga area Jalan Cihampelas dapat menjadi lebih tertata dan rapi tanpa mengganggu, atau bahkan meningkatkan, arus pejalan kaki yang melalui area tersebut. Selain itu, skywalk yang mempunyai ketinggian setara di lantai 3 ketinggian bangunan komersial disekitarnya direncanakan untuk dihubungkan sehingga bangunan komersial dapat diakses dari elevasi yang berbeda.

Dengan adanya Teras Cihampelas, terbentuk elemen-elemen baru di sepanjang pinggiran jalur pedestrian berupa kolom-kolom teras, dimana terdapat juga softscape berupa elemen taman kecil yang mengitari kolom tersebut. Pandangan ke seberang jalan menjadi cukup terbatas dan gelap dengan adanya "atap" di Jalan Cihampelas dapat mengubah perspektif ruang para pejalan kaki di sepanjang jalan. Komunikasi antara fasad bangunan dengan jalan juga menjadi berbeda karena adanya intervensi Teras Cihampelas yang seakan menutupi fasad bangunan di level tertentu jika dilihat dari area pejalan kaki.

Keberadaan Teras Cihampelas menimbulkan perubahan yang signifikan, terutama dalam hal pembentukan ruang antar bangunan di bagian bawah teras yang menjadi sirkulasi pejalan kaki sehingga menyebabkan adanya perbedaan kualitas visual di ruang-ruang antara tersebut. Perbedaan antar kualitas visual yang terbentuk inilah yang membuat pengalaman visual pejalan kaki di koridorjalan menjadi berbeda sehingga dapat dilihat bagaimana dampak dari dari adanya infrastruktur yang baru ini dapat menyebabkan adanya hubungan ruang antar bangunan dengan kualitas visual pejalan kaki yang beraktivitas di area tersebut.

Secara umum, penelitian ini akan membahas bagaimana munculnya sebuah infrastruktur 
kota dapat membentuk kualitas visual di ruang antara bangunan eksisting dengan infrastruktur tersebut, sehingga dapat menghasilkan sebuah perspektif baru dalam menanggapi ruang publik terbuka kota yang multilevel terutama di area eksisting yang terintervensi, yang masih jarang ditemukan di kota Bandung maupun di kota-kota lain di Indonesia.

\section{JALAN CIHAMPELAS}

\subsection{GAMBARAN UMUM}

Jalan Cihampelas merupakan jalan kolektor sekunder yang termasuk dalam Revitalisasi Lima Kawasan Sentra Industri dan Perdagangan Kota Bandung tahun 2008. Jalan ini juga termasuk kedalam Kawasan Pariwisata Belanja dan Warisan Budaya menurut Peraturan Daerah Kota Bandung Nomor 01 Tahun 2013. Terdapat banyak pertokoan jeans dan hotel di Jalan Cihampelas antara lain Parijs van Java, Cihampelas Walk, The Promenade, dan lain-lain yang menjadi daya tarik bagi wisatawan maupun masyarakat Bandung untuk berbelanja dan berkuliner.

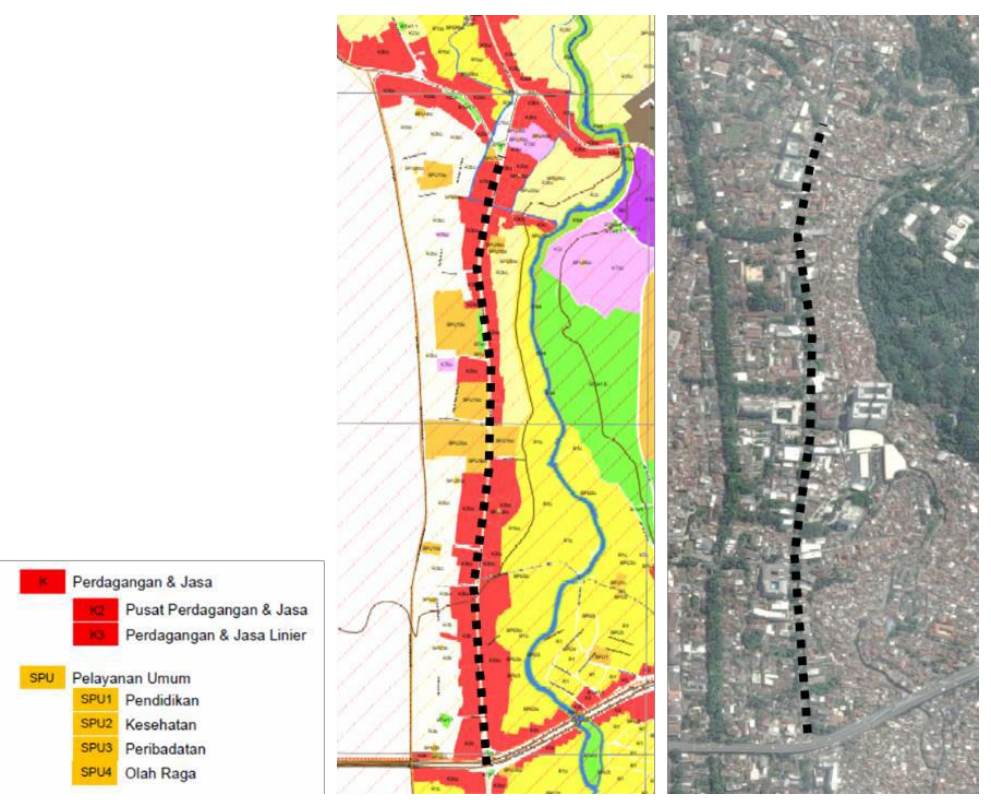

Figur 1. Gambar RDTR dan Citra Satelit Jalan Cihampelas

\subsection{SKYWALK TERAS CIHAMPELAS}

Di dalam Rencana Detail Tata Ruang Dan Peraturan Zonasi Kota Bandung Tahun 2015-2035, Jalan Cihampelas dirancang untuk menjadi kawasan wisata yang ramah pejalan kaki, serta dicanangkan untuk dilakukan pemindahan PKL yang dinilai sudah menjamur di area ini sehingga menyebabkan alur pejalan kaki dan kendaraan bermotor menjadi terhambat. Perencanaan tersebut melahirkan gagasan skywalk Teras Cihampelas. Teras Cihampelas merupakan infrastruktur jenis skywalk yang pertama kali ada di Indonesia. Skywalk ini mencontoh fungsi High Line di New York meskipun berbeda struktur dan sejarah penggunaannya. Teras Cihampelas direncanakan untuk memindahkan PKL dan menambahkan akses pejalan kaki dari lantai dasar ke lantai 2 bangunan, serta menghubungkan skywalk tersebut ke lantai bangunan di sepanjang Jalan Cihampelas sampai dengan Gelap Nyawang. 

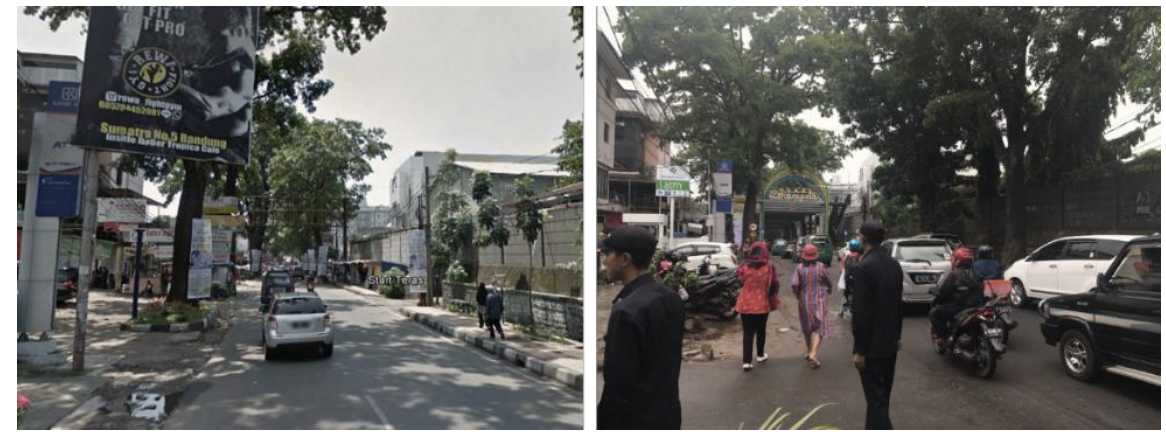

Figur 2. Transformasi Jalan Cihampelas 1
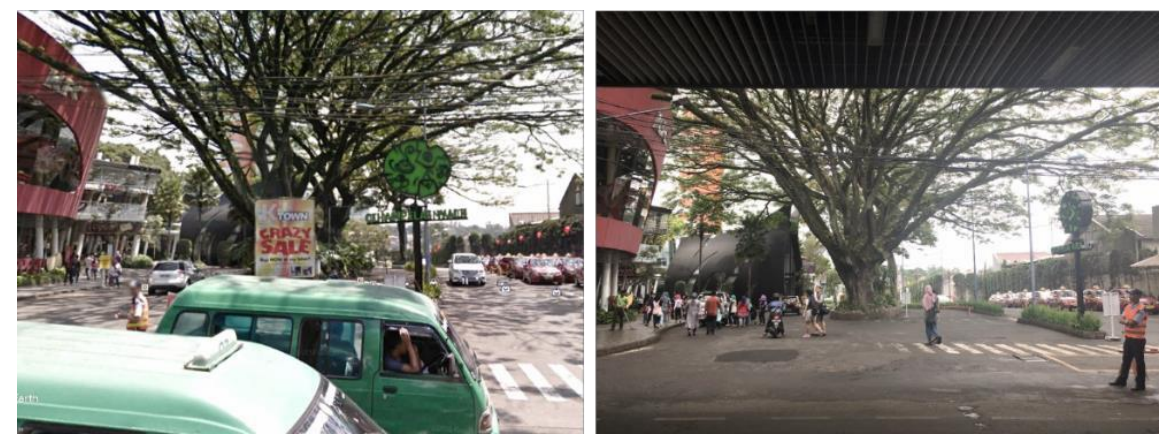

Figur 3. Transformasi Jalan Cihampelas 2
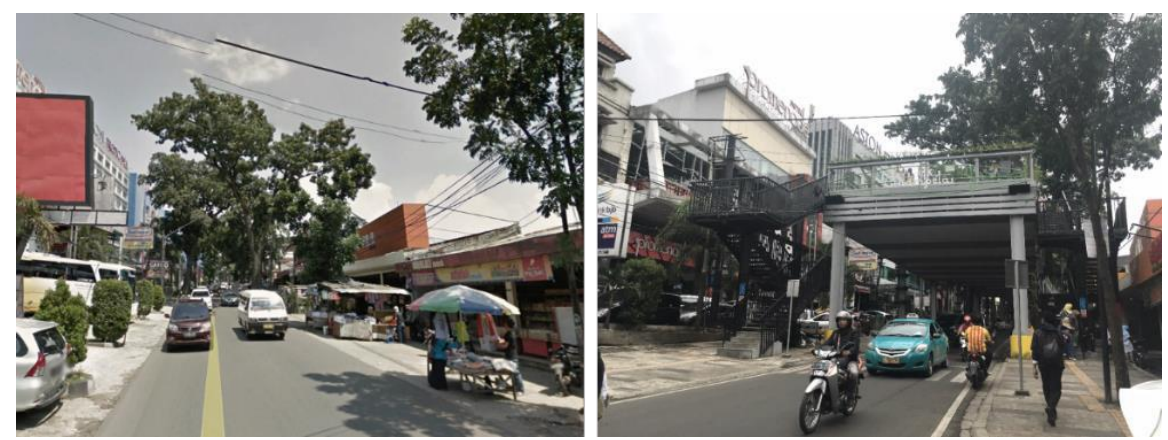

Figur 4. Transformasi Jalan Cihampelas 3

\subsection{INTENSITAS BANGUNAN}

Jalan Cihampelas termasuk kedalam zona K3 yang merupakan Zona Perdagangan dan Jasa Linier dimana GSB yang ada merupakan 50\% dari lebar jalan yaitu 5 meter. Akan tetapi, eksisting pada bangunan di sepanjang jalan Cihampelas tidak seluruhnya mengikuti peraturan ini. Luas lantai maksimum $2.500 \mathrm{~m} 2$ dan tidak dilalui oleh jalur pesawat terbang sehingga ketinggian bangunan dapat disesuaikan dengan luas lahan yang tersedia tanpa adanya batasan ketinggian tertentu. Pemetaan Jalan Cihampelas yang diambil hanya dari titik struktur kolom pertama sampai dengan kolom terakhir Teras Cihampelas $( \pm 450 \mathrm{~m})$ sesuai dengan topik pembahasan yaitu ruang antar bangunan yang disebabkan oleh munculnya infrastruktur teras. 


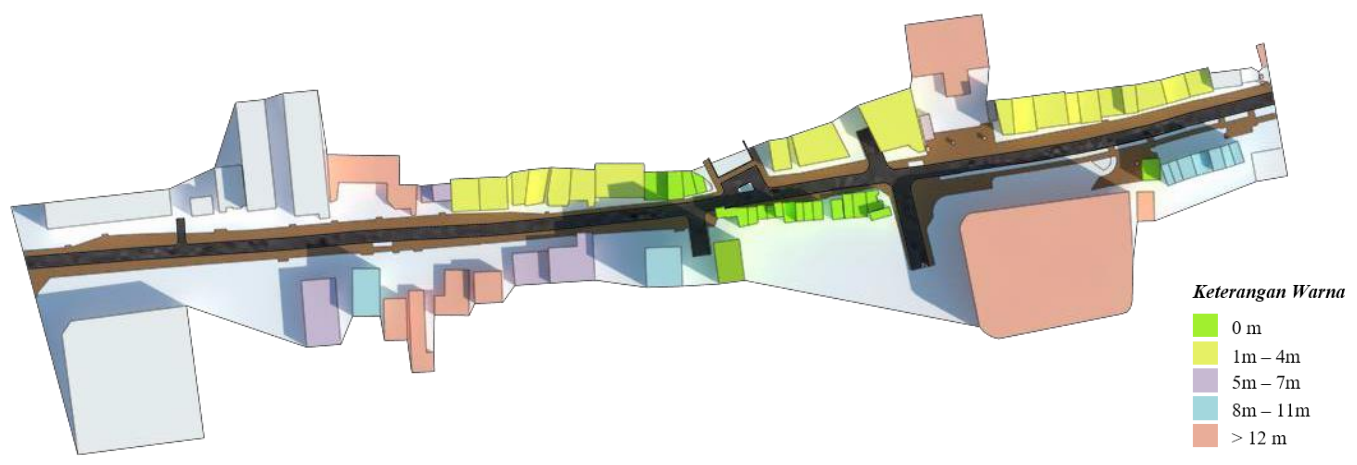

Figur 5. Pemetaan Setback Bangunan di Jalan Cihampelas

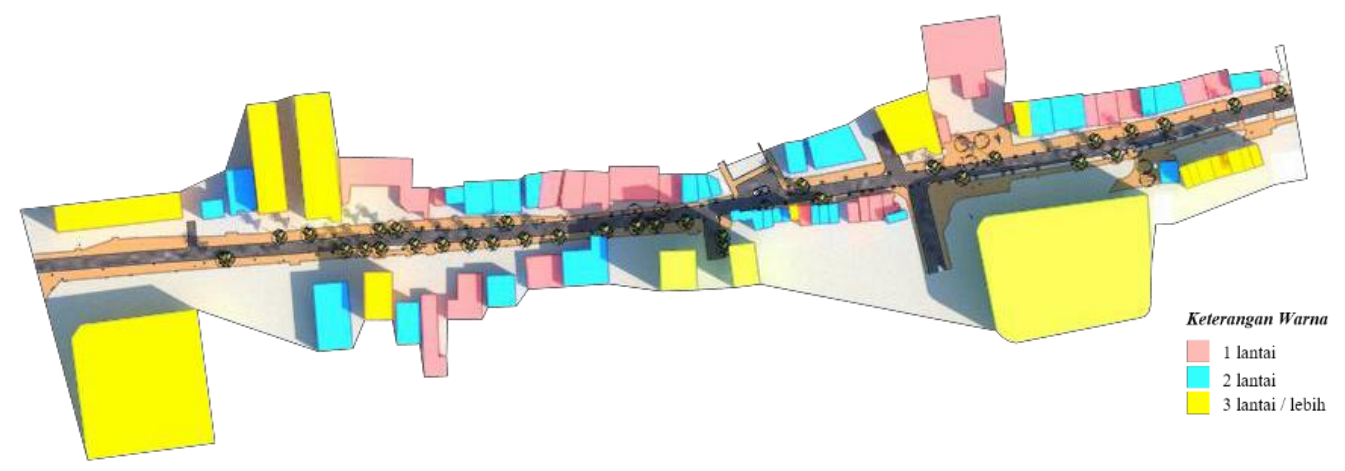

Figur 6. Pemetaan Jumlah Lantai Bangunan di Jalan Cihampelas

\subsection{PEMETAAN TITIK POHON DAN TITIK KOLOM}

Titik pohon dipetakan untuk mengetahui perletakan elemen pelingkup berupa spatial plane dan head plane yang kemudian dapat dianalisis dan mempengaruhi kualitas visual yang ada. Titik kolom Teras Cihampelas dipetakan untuk mengetahui hubungan antara perletakan titik kolom tersebut dengan kavling bangunan eksisting. Selain itu, titik kolom juga menandakan adanya elemen enclosure yang berupa spatial plane (kolom teras) dan head plane (atap Teras Cihampelas yang mengenai area trotoar).

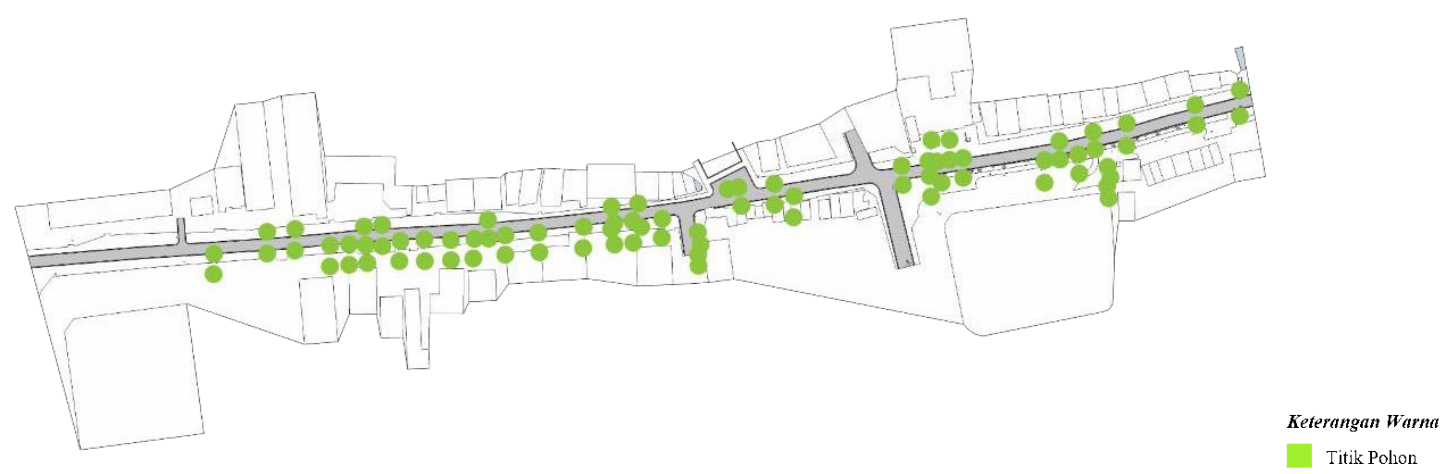

Figur 7. Pemetaan Titik Pohon di Jalan Cihampelas 


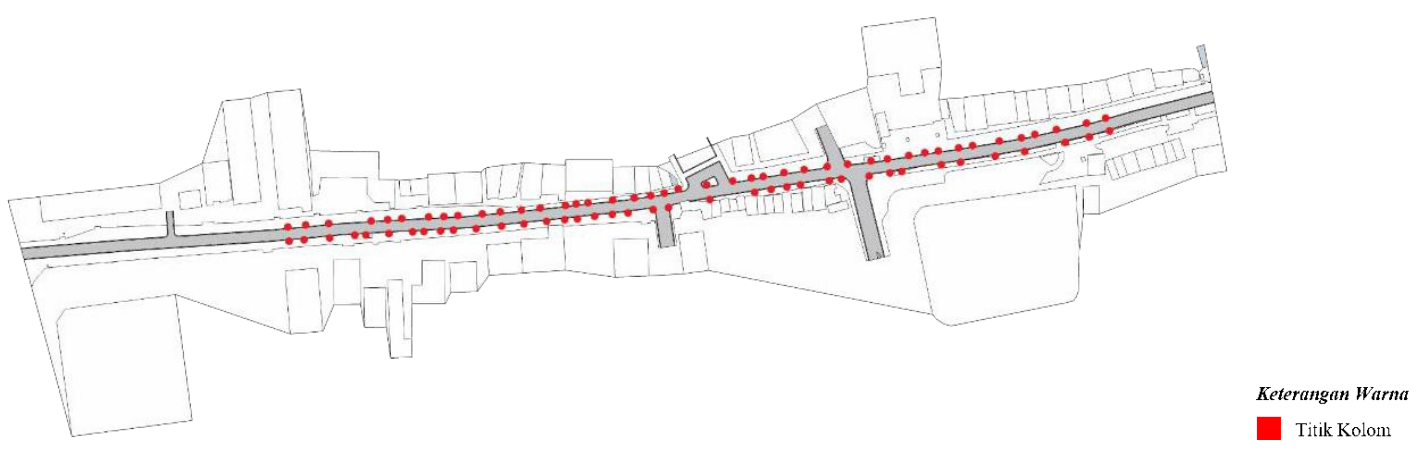

Figur 8. Pemetaan Titik Kolom Teras Cihampelas

\section{TIPOLOGI RUANG ANTAR BANGUNAN DI JALAN CIHAMPELAS}

\subsection{TIPOLOGI RUANG ANTAR BANGUNAN}

Pembagian tipologi ruang antar bangunan didasari oleh pengelompokan setback dan jumlah lantai bangunan. Kedua hal ini mempengaruhi perspektif manusia yang berjalan di sepanjang area trotoar sehingga dapat menjadi dasar yang kuat dalam pengelompokkan untuk mengetahui skala, proporsi, serta kualitas visual yang terjadi. Pada Jalan Cihampelas, terdapat sebanyak 5 tipologi dengan total 14 varian. Tipologi pada jalan ini terbagi menjadi dua jalur besar yaitu trotoar bagian timur dengan trotoar bagian barat. Trotoar bagian barat dibagi kembali menjad 3 segmen, berdasarkan adanya diskontinuitas jalur karena jalan raya atau gang. Trotoar bagian timur juga dibagi kembali menjad 3 segmen, berdasarkan adanya diskontinuitas jalur karena jalan raya atau gang.

\section{Tipologi 1}

Tipologi ini dikategorikan berdasarkan setback bangunan yang sangat kecil yaitu dari 0 m sampai dengan mempunyai kanopi yang menaungi pedestrian. Fungsi bangunan dari tipologi ini seluruhnya merupakan fungsi komersil dimana pada beberapa toko, barang-barangnya dijajakan sampai ke jalur pedestrian. Ketinggian bangunan pun bervariasi dari bangunan 1 lantai sampai dengan 3 lantai.

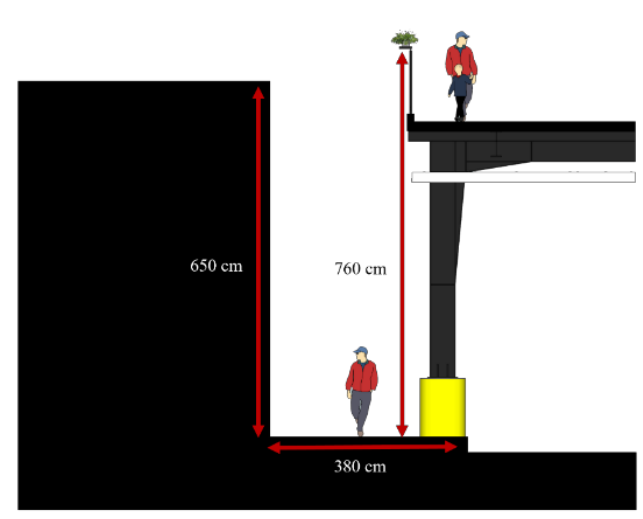

Figur 9. Potongan Skematik Tipologi 1

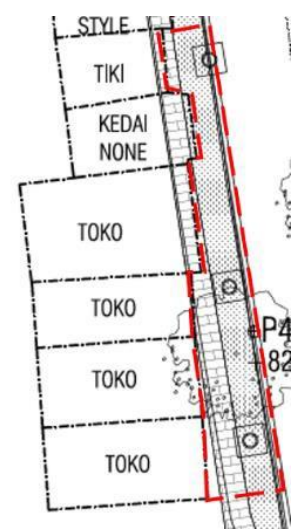

Figur 10. Denah Tipologi 1 


\section{Tipologi 2}

Tipologi ini dikategorikan berdasarkan setback bangunan dari 1 sampai 4 meter dimana sebagian besar berkisar diantara 3 meter. Fungsi bangunan dari tipologi ini merupakan fungsi komersil seperti toko baju, tempat makan, hingga kantor sewa. Ketinggian bangunan di tipologi ini bervariasi dari 1 sampai 3 lantai. Selain itu, pada beberapa toko terdapat lahan parkir di area depan toko hingga ke jalur pedestrian.

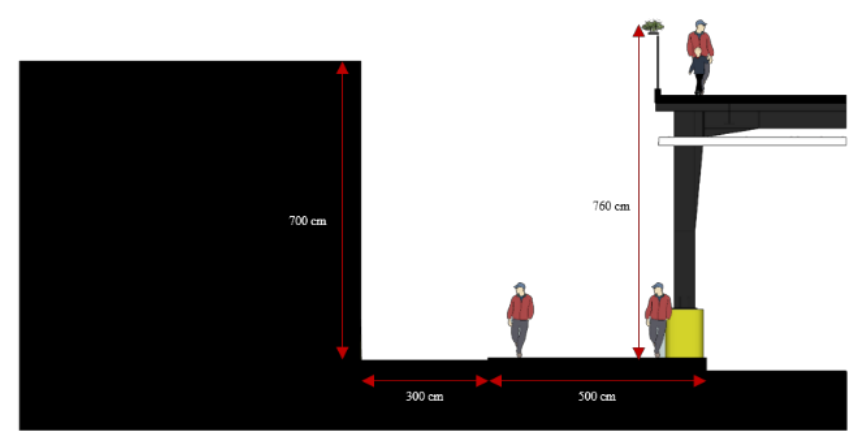

Figur 11. Potongan Skematik Tipologi 2

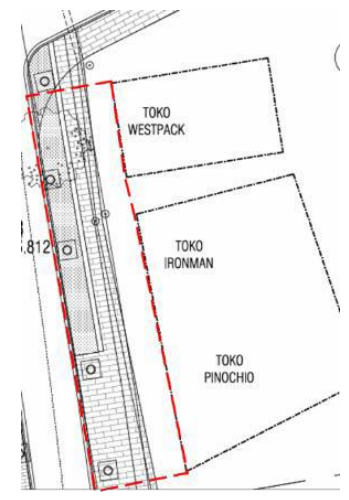

Figur 12. Denah Tipologi 2

\section{Tipologi 3}

Tipologi ini dikategorikan berdasarkan setback bangunan yang lebih dari 12 meter dimana terdapat area parkir atau plaza yang cukup besar berbanding dengan massa bangunan. Fungsi bangunan dari tipologi ini bervariasi dari wisma, toko otomotif, factory outlet, hingga hotel. Ketinggian bangunan di tipologi ini memiliki perbedaan yang cukup jauh dibandingkan tipologi lainnya yakni dari 1 sampai 6 lantai.

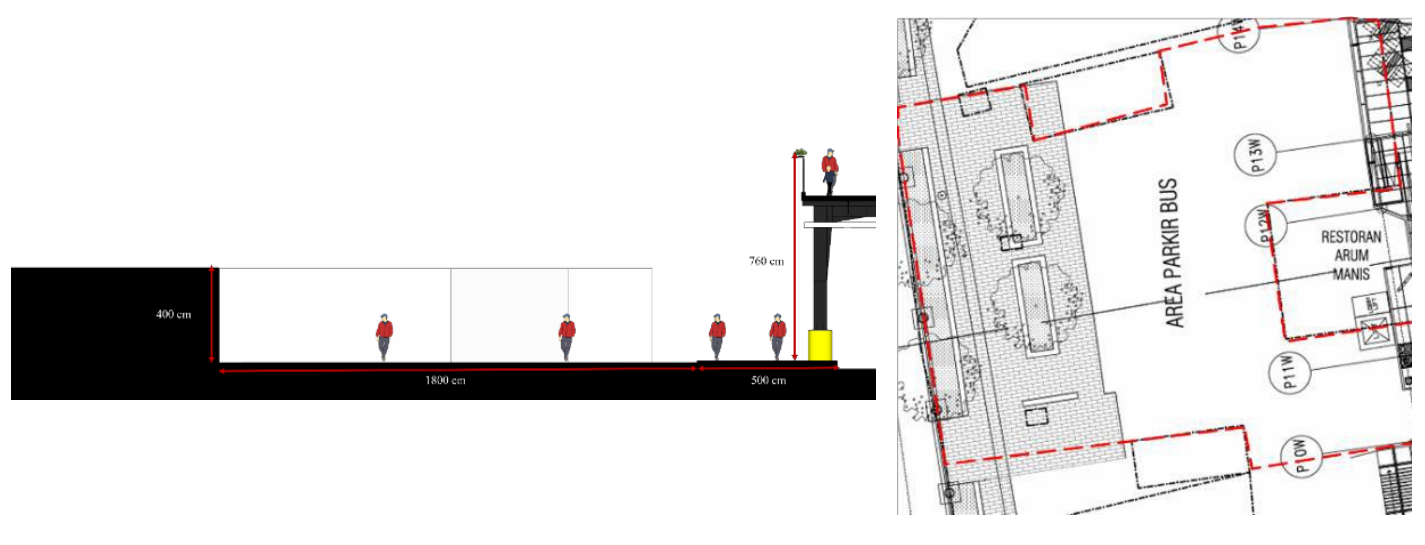

Figur 13. Potongan Skematik Tipologi 3

Figur 14. Denah Tipologi 3

\section{Tipologi 4}

Tipologi 4 dikategorikan berdasarkan setback bangunan dari 8 sampai 11 meter dimana sebagian besar berkisar diantara $9 \mathrm{~m}$. Fungsi bangunan dari tipologi ini merupakan fungsi komersil seperti toko baju dan tempat makan. Ketinggian bangunan di tipologi ini bervariasi dari 1 sampai 3 lantai.

\section{Tipologi 5}

Tipologi 5 merupakan tipologi khusus karena terdapat perbedaan bentuk ruang dan ketinggian bangunan yang signifikan yaitu ruko mixed use dengan hotel serta hotel setinggi 
8 lantai. Pada kedua tipologi ini, ditemui lahan parkir untuk kendaraan bermotor.

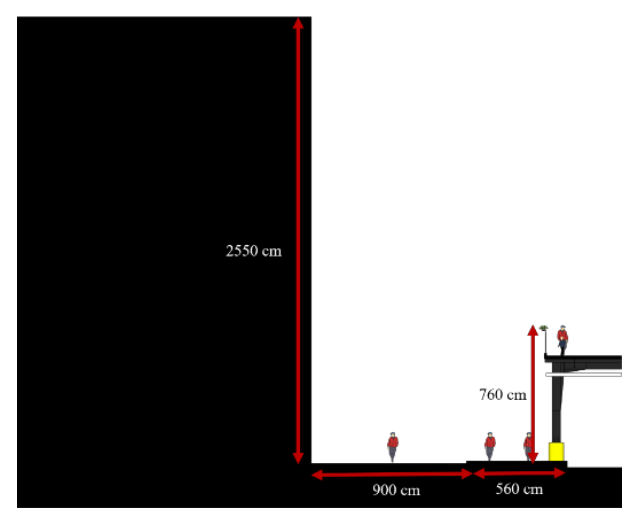

Figur 15. Potongan Tipologi 5

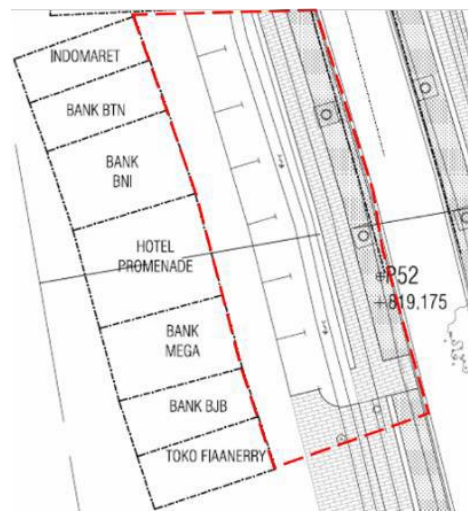

Figur 16. Denah Tipologi 5

\section{Tipologi Keseluruhan Jalan Cihampelas}

Tipologi 1 sampai 5 kemudian dipetakan disepanjang Jalan Cihampelas untuk menemukan hubungan yang runut antar tipologi, terutama untuk menentukan tipologi per ruas trotoar (trotoar timur dan trotoar barat), serta menentukan segmen-segmen yang terbentuk per ruas.

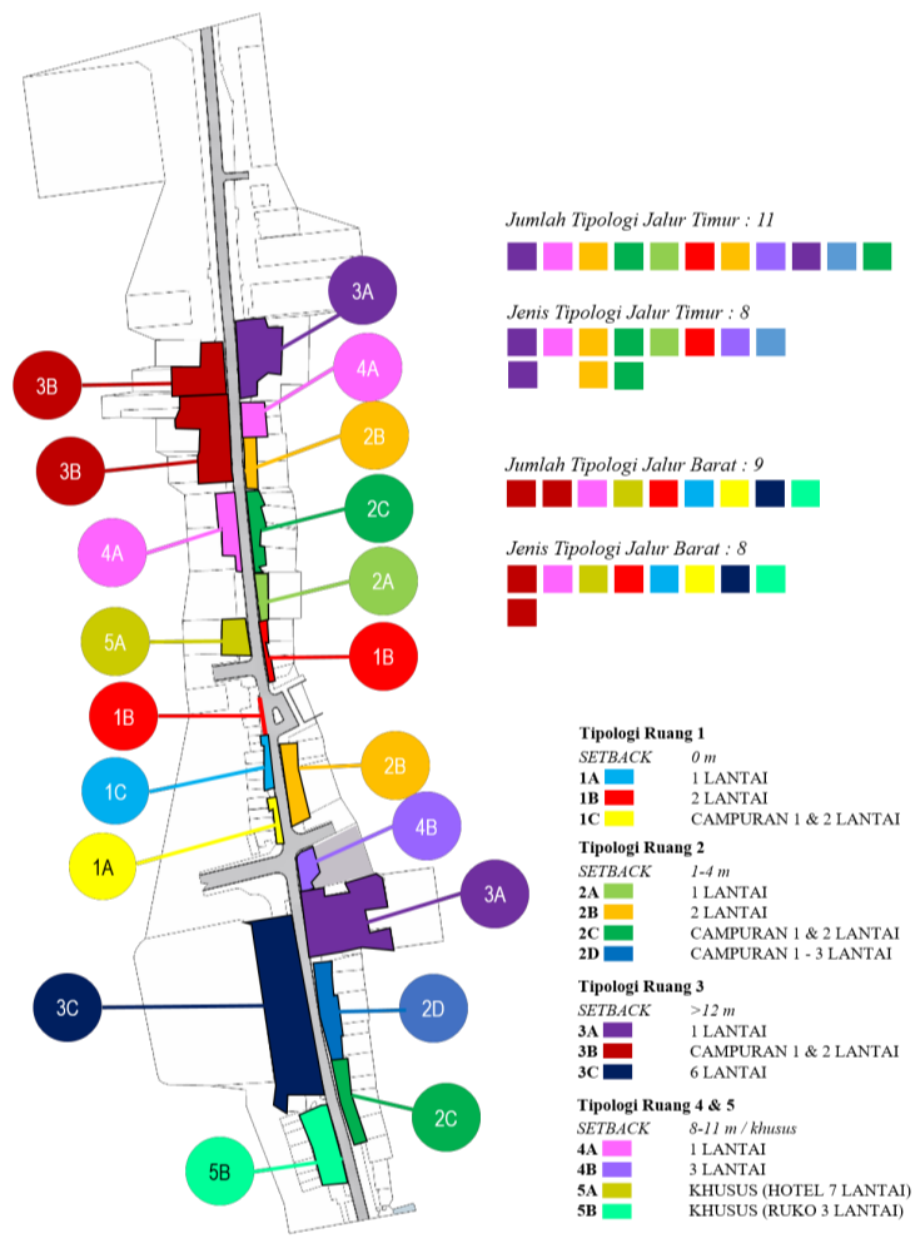

Figur 17. Tipologi Keseluruhan Jalan Cihampelas 


\section{SKALA DAN PROPORSI RUANG DI JALAN CIHAMPELAS}

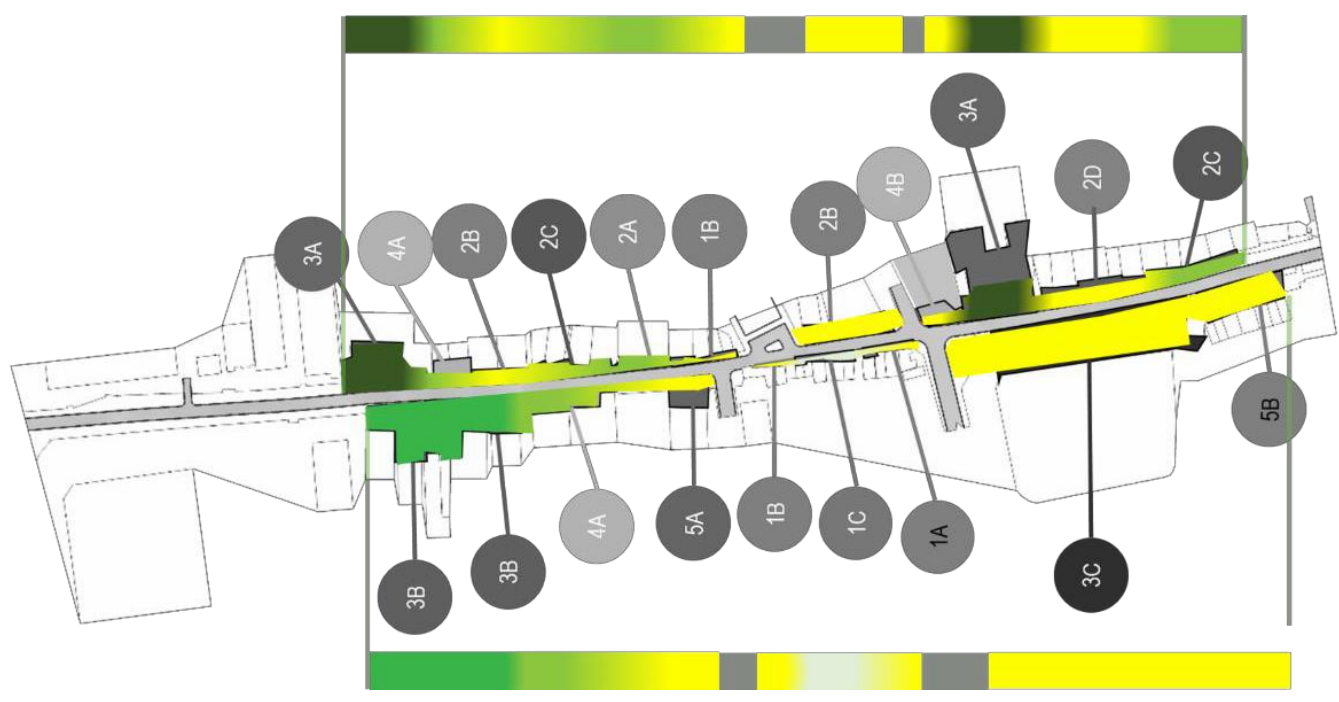

\begin{tabular}{|c|c|}
\hline Tipologi & $\begin{array}{c}\text { Mean } \\
\text { D/H }\end{array}$ \\
\hline $1 \mathrm{~A}$ & 0.89 \\
\hline $1 \mathrm{~B}$ & 0.63 \\
\hline $1 \mathrm{C}$ & 0.41 \\
\hline $2 \mathrm{~A}$ & 1.70 \\
\hline $2 \mathrm{~B}$ & 1.20 \\
\hline $2 \mathrm{C}$ & 1.86 \\
\hline $2 \mathrm{D}$ & 1.43 \\
\hline $3 \mathrm{~A}$ & 4.90 \\
\hline $3 \mathrm{~B}$ & 2.50 \\
\hline $3 \mathrm{C}$ & 1.00 \\
\hline $4 \mathrm{~A}$ & 2.05 \\
\hline $4 \mathrm{~B}$ & 1.00 \\
\hline $5 \mathrm{~A}$ & 0.60 \\
\hline $5 \mathrm{~B}$ & 1.0 \\
\hline
\end{tabular}

Skala Ruang Pejalan Kaki (Menurut Yoshinobu Ishihara \& Paul D. Sprieregen)

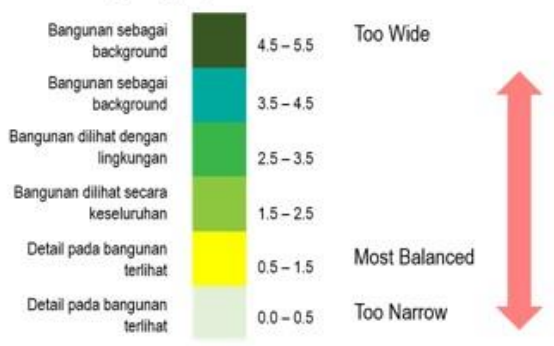

Figur 18. Grafik Warna Skala dan Proporsi Ruang Antara Jalan Cihampelas

Pada ruas trotoar bagian timur jalan, trotoar dapat dibagi menjadi tiga segmen karena adanya dua jalan kendaraan yang memisahkan seluruh ruas panjang, antara lain: (1) Segmen 1 mempunyai rerata $\mathrm{D} / \mathrm{H}$ sebesar 2,32 yang menunjukkan bahwa area ini mempunyai proporsi ruang yang cukup besar dan lebar, serta pejalan kaki akan cenderung melihat fasad bangunan secara menyeluruh. (2) Segmen 2 mempunyai rerata D/H sebesar 1,2 yang menunjukkan bahwa area ini mempunyai proporsi ruang yang cukup seimbang, serta pejalan kaki akan cenderung melihat detail pada bangunan dibanding keseluruhan fasadnya. (3) Segmen 3 mempunyai rerata 2,24 yang menunjukkan bahwa area ini mempunyai proporsi ruang yang cukup besar dan lebar, serta pejalan kaki akan cenderung melihat fasad bangunan secara menyeluruh.

Pada ruas trotoar bagian barat jalan, trotoar dapat dibagi menjadi tiga segmen karena adanya dua jalan kendaraan yang memisahkan seluruh ruas panjang, antara lain: (1) Segmen 4 mempunyai rerata $\mathrm{D} / \mathrm{H}$ sebesar 2,32 yang menunjukkan bahwa area ini mempunyai proporsi ruang yang cukup besar dan lebar, serta pejalan kaki akan cenderung melihat fasad bangunan secara menyeluruh. (2) Segmen 5 mempunyai rerata D/H sebesar 0.65 yang menunjukkan bahwa area ini mempunyai proporsi ruang yang cukup seimbang, serta pejalan kaki akan cenderung melihat detail pada bangunan dibanding keseluruhan fasadnya. (3) Segmen 6 mempunyai rerata $\mathrm{D} / \mathrm{H}$ sebesar 1 yang menunjukkan bahwa area ini mempunyai proporsi ruang yang optimal dan seimbang, serta pejalan kaki akan cenderung 
melihat detail pada bangunan dibanding keseluruhan fasadnya.
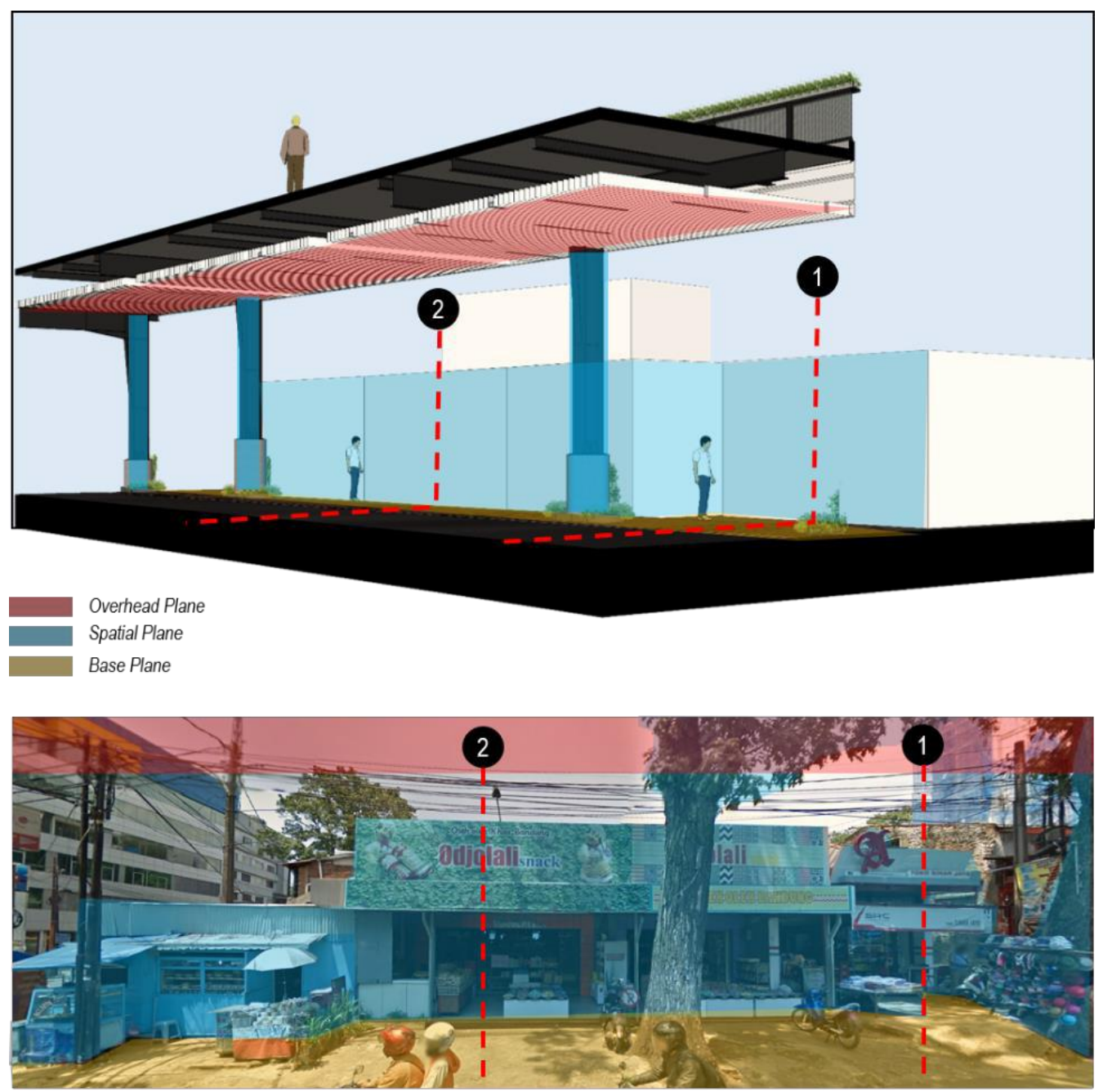

Figur 19. Contoh Analisis Skala, Proporsi dan Enclosure 1 Tipologi

Dari analisis skala dan proporsi antar tipologi ruang antara dapat diperoleh D/H pada trotoar bagian barat yaitu sebesar 2,23. Hal ini menunjukkan bahwa ruas ini mempunyai proporsi ruang yang cukup besar dan lebar (48\% lebih lebar dibanding proporsi optimal). Dari analisis tersebut, diperoleh juga $\mathrm{D} / \mathrm{H}$ pada trotoar bagian timur yaitu sebesar 1,50. Hal ini menunjukkan bahwa ruas ini mempunyai proporsi ruang yang optimal (masuk didalam range optimal 0.5 sampai 1.5 ).

Dengan demikian, dapat dikatakan bahwa skala dan proporsi bangunan secara kesuluruhan di Jalan Cihampelas lebih terjaga dan optimal pada ruas jalan bagian barat. 

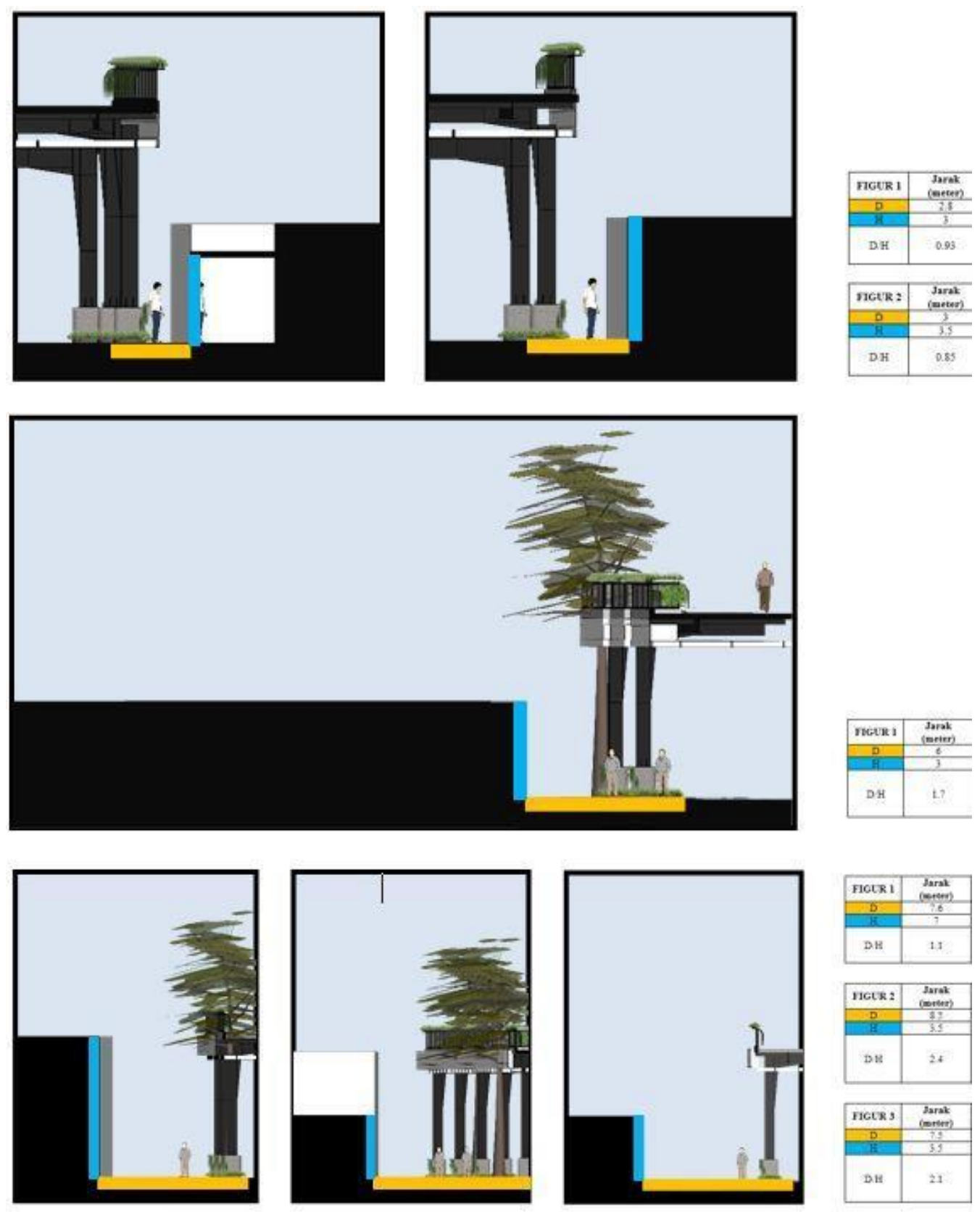

Figur 20. Contoh Analisis Skala dan Proporsi Antar Tipologi Ruang Antara 


\section{KUALITAS WALKABILITY DI JALAN CIHAMPELAS}

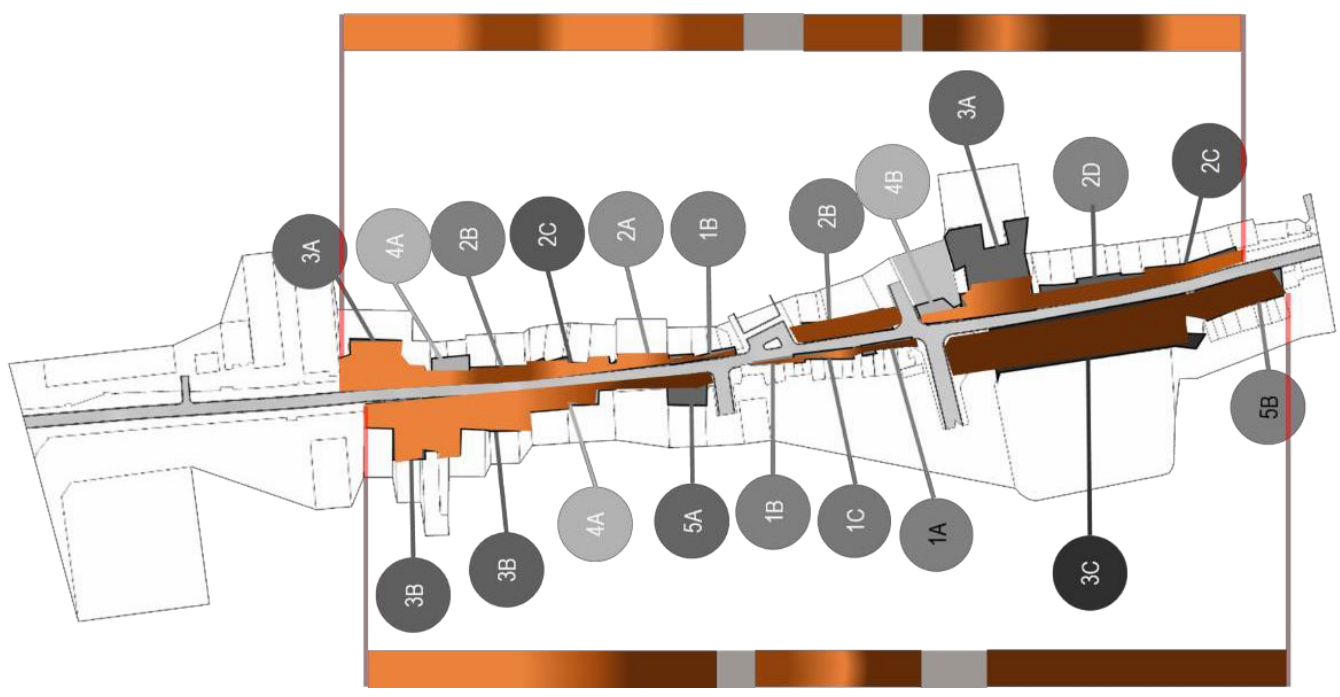

\begin{tabular}{|c|c|c|}
\hline Tipologi & $\begin{array}{c}\text { Total } \\
\text { Poin }\end{array}$ & $\begin{array}{c}\text { Persentase Kualitas } \\
(\%)\end{array}$ \\
\hline 1A & $20 / 28$ & 71.4 \\
\hline 1B & $18 / 28$ & 64.2 \\
\hline 1C & $14 / 28$ & 50 \\
\hline 2A & $16 / 28$ & 57.1 \\
\hline 2B & $18 / 28$ & 64.2 \\
\hline 2C & $16 / 28$ & 57.1 \\
\hline 2D & $22 / 28$ & 78.6 \\
\hline 3A & $16 / 28$ & 57.1 \\
\hline 3B & $16 / 28$ & 57.1 \\
\hline 3C & $21 / 28$ & 75 \\
\hline 4A & $16 / 28$ & 57.1 \\
\hline 4B & $23 / 28$ & 82.1 \\
\hline 5A & $21 / 28$ & 75 \\
\hline 5B & $22 / 28$ & 78.6 \\
\hline
\end{tabular}

Overall Walkability Qualities (Reid Ewing, Pedestrian-\& Transit-Oriented Design)

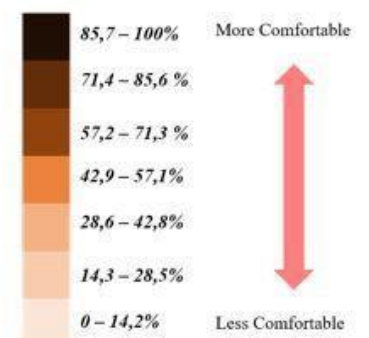

Figur 21. Grafik Warna Kualitas Walkability Jalan Cihampelas

Pada ruas trotoar bagian timur jalan, trotoar dapat dibagi menjadi tiga segmen karena adanya dua jalan kendaraan yang memisahkan seluruh ruas panjang, antara lain: (1) Segmen 1 mempunyai rerata persentase sebesar 59,4\% yang menunjukkan bahwa kualitas walkability yang terpenuhi kurang dari dua pertiga kualitas maksimal tetapi masih diatas batas kenyamanan. (2) Segmen 2 mempunyai rerata persentase sebesar 64,2\% yang menunjukkan bahwa kualitas walkability yang terpenuhi kurang dari dua pertiga kualitas maksimal tetapi masih diatas batas kenyamanan. (3) Segmen 3 mempunyai rerata persentase sebesar $68,4 \%$ yang menunjukkan bahwa kualitas walkability yang terpenuhi lebih dari dua pertiga kualitas maksimal sehingga dapat dinilai cukup nyaman untuk pejalan kaki. Dari analisis tersebut dapat diperoleh persentase walkability pada trotoar bagian barat yaitu sebesar $63,4 \%$.

Pada ruas trotoar bagian barat jalan, trotoar dapat dibagi menjadi tiga segmen karena adanya dua jalan kendaraan yang memisahkan seluruh ruas panjang, antara lain: (1) Segmen 4 mempunyai rerata persentase sebesar $63,8 \%$ yang menunjukkan bahwa kualitas walkability yang terpenuhi kurang dari dua pertiga kualitas maksimal tetapi masih diatas batas kenyamanan. (2) Segmen 5 mempunyai rerata persentase sebesar 61,6\% yang menunjukkan bahwa kualitas walkability yang terpenuhi kurang dari dua pertiga kualitas maksimal tetapi masih diatas batas kenyamanan. (3) Segmen 6 mempunyai rerata persentase sebesar 76,2\% yang menunjukkan bahwa kualitas walkability yang terpenuhi lebih dari dua pertiga kualitas maksimal sehingga dapat dinilai cukup nyaman untuk pejalan kaki. 
Tabel Presentase Kriteria Walkability Per Tipologi

(Tabel yang diwarnai merah berarti kriteria tersebut tidak mencukupi)

\begin{tabular}{|l|r|r|r|r|r|r|r|r|r|r|r|r|r|r|}
\hline $\begin{array}{l}\text { Tipologi } \\
\text { /Kriteria }\end{array}$ & 1A & 1B & 1C & 2A & 2B & 2C & 2D & 3A & 3B & 3C & 4A & 4B & 5A & 5B \\
\hline Visual Enclosure & 80 & 60 & 40 & 40 & 60 & 40 & 80 & 40 & 40 & 100 & 40 & 80 & 100 & 100 \\
\hline Transparency & 67 & 67 & 67 & 67 & 67 & 67 & 67 & 33 & 67 & 33 & 67 & 67 & 67 & 67 \\
\hline Legilibility & 33 & 33 & 0 & 33 & 33 & 33 & 100 & 33 & 33 & 100 & 33 & 100 & 67 & 67 \\
\hline Complexity & 80 & 80 & 80 & 80 & 80 & 80 & 60 & 80 & 80 & 60 & 80 & 60 & 60 & 60 \\
\hline Human Scale & 75 & 75 & 50 & 50 & 75 & 50 & 75 & 50 & 50 & 75 & 50 & 100 & 75 & 75 \\
\hline Coherence & 100 & 100 & 100 & 100 & 100 & 100 & 100 & 100 & 67 & 100 & 100 & 100 & 67 & 100 \\
\hline Imageability & 60 & 40 & 20 & 40 & 40 & 40 & 80 & 60 & 60 & 60 & 40 & 100 & 80 & 80 \\
\hline Jumlah & 495 & 455 & 357 & 410 & 455 & 410 & 562 & 396 & 397 & 528 & 410 & 607 & 516 & 549 \\
\hline $\begin{array}{l}\text { Rata2 } \\
\text { Persentase }\end{array}$ & $\mathbf{7 1}$ & $\mathbf{6 5}$ & $\mathbf{5 1}$ & $\mathbf{5 9}$ & $\mathbf{6 5}$ & $\mathbf{5 9}$ & $\mathbf{8 0}$ & $\mathbf{5 7}$ & $\mathbf{5 7}$ & $\mathbf{7 5}$ & $\mathbf{5 9}$ & $\mathbf{8 7}$ & $\mathbf{7 4}$ & $\mathbf{7 8}$ \\
\hline
\end{tabular}

Tabel Presentase Kriteria Walkability Per Segmen Jalan

(Tabel yang diwarnai merah berarti kriteria tersebut tidak mencukupi)

\begin{tabular}{|l|r|r|r|r|r|r|}
\hline Kriteria/Segmen & S1 & \multicolumn{1}{|c|}{ S2 } & S3 & S4 & S5 & S6 \\
\hline Visual Enclosure & 47 & 60 & 60 & 63 & 60 & 100 \\
\hline Transparency & 59 & 67 & 60 & 67 & 67 & 44 \\
\hline Legilibility & 33 & 33 & 67 & 46 & 21 & 89 \\
\hline Complexity & 80 & 80 & 70 & 73 & 80 & 60 \\
\hline Human Scale & 58 & 75 & 66 & 59 & 66 & 75 \\
\hline Coherence & 100 & 100 & 100 & 75 & 100 & 100 \\
\hline Imageability & 44 & 40 & 67 & 63 & 40 & 67 \\
\hline
\end{tabular}

Figur 21. Tabel Presentase Detail Kriteria Kualitas Walkability Tipologi Ruang Antara pada Jalan Cihampelas

Dari analisis tersebut dapat diperoleh rata-rata persentase walkability pada trotoar bagian timur yaitu sebesar $63,4 \%$ dan pada trotoar bagian barat yaitu sebesar $67,4 \%$. Dengan demikian, dapat disimpulkan bahwa trotoar bagian timur mempunyai kualitas walkability yang lebih tinggi dibandingkan bagian barat.

\section{PENUTUP}

Berdasarkan analisis yang telah dilakukan, dapat ditarik kesimpulan berupa pengalaman visual yang dapat terbentuk dalam penelitian Pengaruh Skala, Proporsi, dan Walkability terhadap Kualitas Visual Trotoar di bawah Teras Cihampelas. Kualitas visual pejalan kaki dapat digambarkan dengan penggabungan grafik warna dari analisis skala dan proporsi ruang dengan grafik warna dari analisis kualitas walkability yang ditinjau dari elemen visual.

Dalam perancangan trotoar selanjutnya, lebar jalan trotoar sebaiknya sesuai dengan perbandingannya dengan setback dan ketinggian bangunan sehingga tercapai proporsi yang optimal. Dalam perancangan bangunan yang mempunyai akses langsung dari pedestrian, skala ruang eksterior sebaiknya harus tetap humanis dengan penambahan kanopi / elemen lain. 
Elemen-elemen pembentuk walkability ruang seperti keterlingkupan, kejelasan, dan imageability harus diperhatikan karena hampir seluruh tipologi mendapatkan poin yang sedikit dari ketiga faktor ini.

Dengan demikian, kualitas visual pada trotoar terutama di Jalan Cihampelas dapat ditingkatkan kenyamanan baik dalam faktor skala ruang dan walkability-nya.

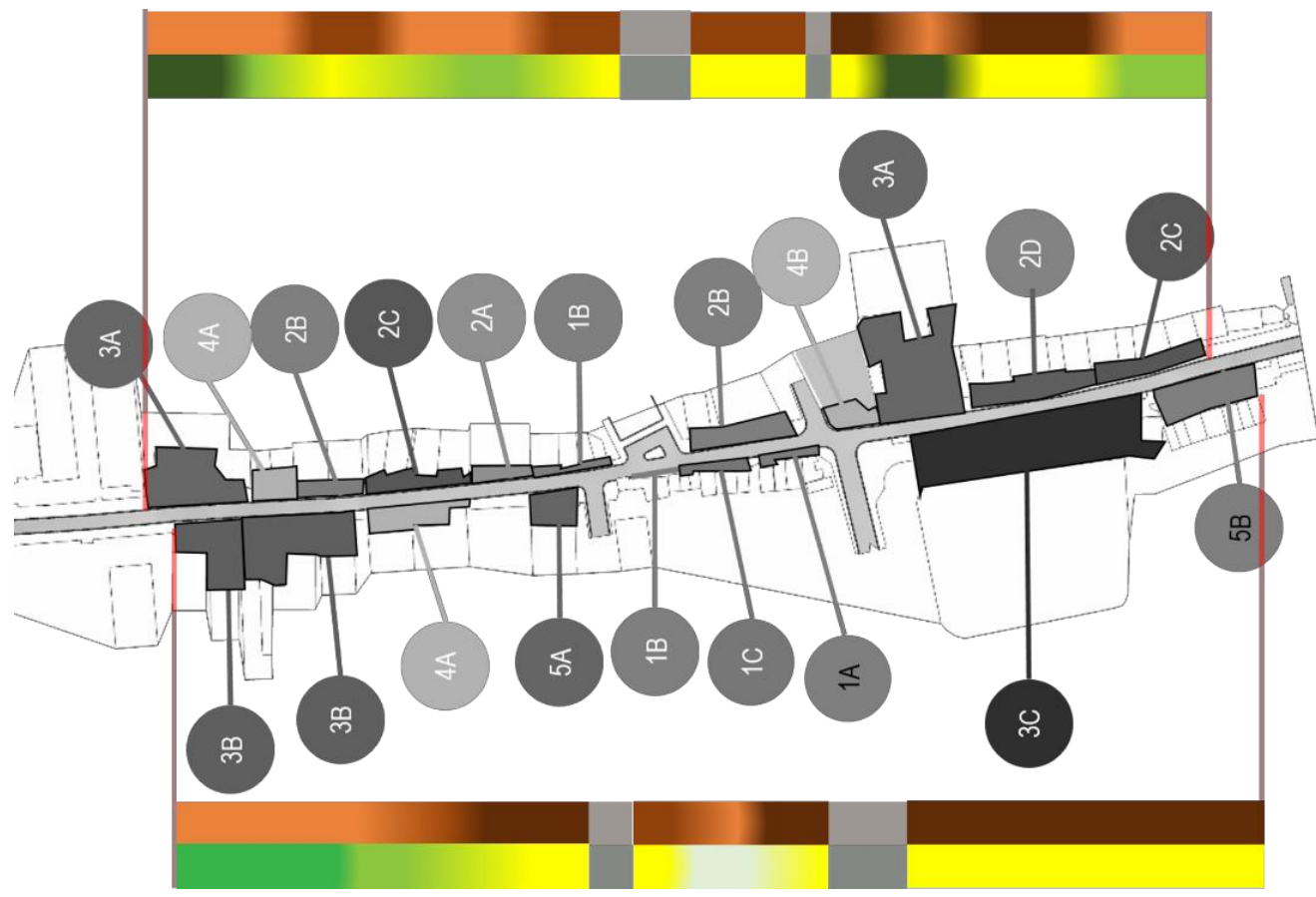

Overall Walkability Qualities (Reid Ewing,

Skala Ruang Pejalan Kaki (Menurut Yoshinobu Ishihara Pedestrian- \& Transit-Oriented Design) \& Paul D. Sprieregen)
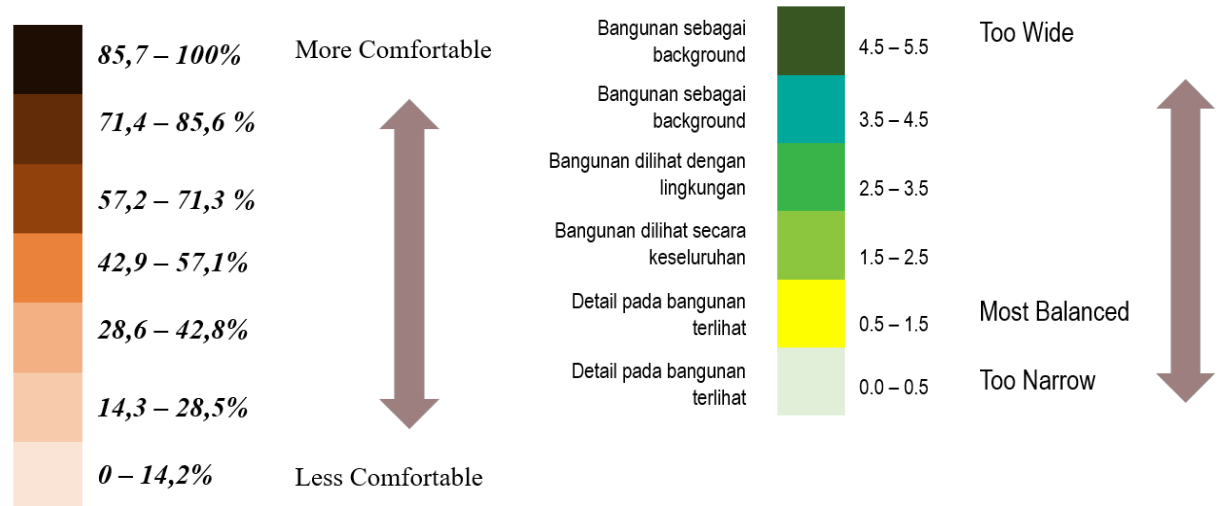

Figur 22. Grafik Warna Kesimpulan Pengalaman Visual pada Jalan Cihampelas

\section{DAFTAR PUSTAKA}

Ashihara, Yoshinobu. 1970. Exterior Design In Architecture. New York: Van Nostrand Reinhold Company.

Spreiregen, Paul. 1965. Urban Design: The Architecture of Towns and Cities. New York: McGraw-Hill Book Company.

Ewing, Reid. 2012. Pedestrian and Transit Oriented Design. Washington: Urban Land Institute. 